A. Berlach, Dr. Sc. (Law), Prof.

Taras Shevchenko National University of Kyiv, Kyiv, Ukraine

\title{
INSTITUTE OF PUBLIC SERVANTS RESPONSIBILITY IN THE SYSTEM OF SERVICE LAW OF UKRAINE
}

The article is devoted to the research of the institute of responsibility of public servants in the system of service law of Ukraine. It is emphasized the importance of legal support for the functioning of the public service system, in particular the regulation of the mechanism of responsibility of public servants. It is noted that the institution of responsibility is a mandatory element of the system of every branch of law, including official, because it is this legal entity whose task is to ensure the proper implementation of the legal status of every public servant.

Considering the responsibility of public servants from the standpoint of social and legal content, the author emphasizes that the views of scholars on this issue are very different, as they reflect the palette of the worldview of each individual researcher and characterize the various aspects of public relations. In a wide sense, responsibility is a legal relationship between public authorities in the person of its authorized bodies and subjects of law, for the accurate and conscientious implementation of the requirements contained in the relevant rules of law.

Analyzing the scientific views of scholars on responsibility, it is emphasized that in general, the liability of public servants should be understood as a procedurally established application of coercive measures of coercive influence on a particular public person for committing an offense.

It is stated that the content of the legal nature of the institute of disciplinary responsibility of public servants, in particular in the system of service law of Ukraine, which needs proper research, remains important and extremely necessary for law enforcement and human rights activities of authorized subjects.

Based on the analysis of scientific achievements of local and foreign scholars on the legal system, it is emphasized that currently there are different approaches to understanding the systemic structure of legal branches, in particular some scholars remain on the views developed in our time, while others try to adapt European researchers-lawyers on the system of law on modern Ukrainian realities.

As a result, the author emphasizes that we can now state that each branch of law, which we call general, special or special law, always contains a list of legal norms in the appropriate relationship and sequence and thus ensuring the ability of the subject of rule-making, law enforcement or human rights activities to achieve the desired result - to create or harmonize existing social relations, giving them the status of legal relations.

Keywords: public service, service law, responsibility, legal system, general, special and special part, sanctions.

Bulletin of Taras Shevchenko National University of Kyiv. Legal Studies, 2021; 3 (118): 9-14

УдК 347

DOI: https:doi.org/10.17721/1728-2195/2021/3.118-2
ISSN 1728-2195

(C) Taras Shevchenko National University of Kyiv, Publishing center "Kyiv University", 2021

\section{ЕВОЛЮЦІЯ ВЧЕННЯ ПРО ДОВІРЧІ ВІДНОСИНИ В НЕЗАЛЕЖНІЙ УКРАЇНІ: ВІД ПОВНОГО ЗАПЕРЕЧЕННЯ ДО ВПРОВАДЖЕННЯ У ЧИННЕ ЗАКОНОДАВСТВО}

Статтю присвячено розвитку вчення про довірчі відносини в Україні. Перш за все, ідеться про зміну розуміння українським суспільством ідеї трасту та інших трастоподібних конструкцій з 90-х років ХХ століття і до сьогодення.

Метою статmі є висвітлення основних етапів і підходів до розуміння довірчих відносин загалом і трасту й інших довірчих конструкцій зокрема, а також аналіз їхніх спільних і відмінних рис порівняно із суміжними правовими інститутами задля визначення перспектив подальшого впровадження у право України.

Для висвітлення різних підходів до розуміння трастів та паратрастових конструкцій під час написання статті використано порівняльно-історичний метод, а також методи аналізу, сходження від абстрактного до конкретного та системно-структурний методи наукового пізнання.

Нерозуміння ідеї трасту призвело до порушення прав громадян, які, постраждали від фінансових афер довірчих товариств, що відіграло не останню роль у формуванні недовірливого або відверто негативного ставлення юристів і звичайних громадян в Україні до трастів та інших довірчих конструкцій упродовж майже двох десятиліть.

Поняття трасту існує у праві України досить тривалий час, проте переважно воно асоціюється 3 негативом переховуванням майна, приховуванням інформації про кінцевих бенефіціарних власників тощо. Поняття трасту зазнає постійних змін, що свідчить про еволюцію підходів до розуміння цього інституту. Нині траст розуміють як "правовідносини", тоді як попередня редакція закону визначала траст через категорію юридичної особи.

Підхід до розуміння поняття бенефіціарної власності у трасті відрізняється у країнах загального права та в $\mathrm{Y}_{\text {к- }}$ раїні. В Україні під це визначення підпадає право фізичної особи, яка незалежно від формального володіння має можливість здійснювати вирішальний вплив на управління або господарську діяльність юридичної особи безпосередньо або через інших осіб.

Ключові слова: довірчі відносини, траст, трастоподібні (паратрастові) конструкції, управління майном, Конвенція про трасти, бенефіціарна власність, довірчий власник, кінцевий бенефіціарний власник, вигодонабувач, контрольована іноземна компанія (КІК), відкличні трасти, безвідкличні трасти.

\section{ВСТУП}

Учення про довірчі відносини має глибоке коріння, що сягає на декілька тисячоліть у давнину. У різних народів завжди існували правові інститути, які базувалися не стільки на нормах права (а відповідно і на примусі), скільки на довірі та морально-етичних нормах. Вони стосувалися різних сфер життя, наприклад, це могли бути відносини пацієнта з лікарем, тобто коли одна особа, покладаючись на авторитет і повагу до конкретної особи або до фраху (лікаря) "довіряла" вирішення її проблемних питань цій особі. Людина "вірила", що лікар зможе допомогти їй, використовуючи власні знання та досвід.

Водночас досить часто довірчі відносини використовували саме у сорері передачі майна. Яскравим прикладом можуть слугувати такі інститути, які передбачали передачу майна від власника іншим (довіреним) особам із метою управління на користь певних осіб. У різних країнах указані інститути могли мати різні назви та застосовуватися для різних потреб, хоча переважно вони використовувалися 3 метою управління майном на користь недієздатних або обмежено дієздатних осіб (починаючи від дітей, закінчуючи жінками, які мали різний обсяг дієздатності у різні часи). Тому виникнення довірчих відносин управління майном не $є$ чимось локальним або унікальним - навпаки, це реакція на виклики часу, яка мала місце у різних народів, оскільки люди у різних куточках світу часто стикалися зі схожими потребами або проблемами.

Якщо ж говорити про наш час, то з поняттям "довірчих" відносин часто асоціюють відносини трасту. Без сумніву, трастові відносини поряд із відносинами управ- 
ління майном входять до поняття довірчих відносин, проте з ним аж ніяк не ототожнюються. I незважаючи на той факт, що з моменту набуття Україною незалежності науковцями захищено близько десятка робіт, які розвінчують міфри і про довірчі відносини загалом, і про трасти зокрема, усе одно до цього часу пересічні громадяни ставляться до цих інститутів з пересторогою. Звичайно, цьому $є$ логічне пояснення. Так, на початку $90-x$ років XX століття у законодавстві України поступово починають з'являтися нові терміни, такі як: "довірчі операції", "довірча власність", "траст", "довірче управління", "бенефріціарій" тощо. Крім того, зазначені терміни фігурують у багатьох законопроєктах, зокрема й у проєкті Цивільного кодексу України. Указані поняття іноді ототожнюють, іноді в них вкладають подібний (але не повністю) зміст, хоча найчастіше вони залишаються не до кінця визначеними.

На жаль, нерозуміння ідеї трасту призвело до порушення прав громадян, які, постраждали від фінансових aфер довірчих товариств і первісних, так званих трастів, що зіграло не останню роль у формуванні недовірливого або відверто негативного ставлення юристів i звичайних громадян до трастів та інших довірчих конструкцій упродовж майже двох десятків років.

Отже, нині перед науковцями, практиками й органами державної влади постає непросте завдання - зламати стереотипи, які існують у суспільстві щодо трастів та їхніх аналогів в інших країнах, та довести, що ці інститути можна успішно використовувати для досягнення легальних і суспільно корисних цілей.

\section{ОСНОВНІ РЕЗУЛЬТАТИ}

У цій статті під довірчими правовідносинами ми пропонуємо розуміти правовідносини, які ґрунтуються на особливій довірі власника майна (довірителя) до довірчого власника/управителя, що виникають під час передачі майна довірителем у власність або в управління довірчому власнику/управителю з метою управління цим майном в інтересах указаної власником особи (бенефіціарія або вигодонабувача) або для досягнення певної мети.

Довірчі правовідносини зазвичай поділяють на дві великі групи, а саме: відносини, які передбачають перехід права власності на передане майно (траст або довірча власність), та відносини, які не передбачають переходу права власності на майно до управителя (довірче управління й інші трастоподібні конструкції).

Пропонуємо детальніше зупинитися на понятті трасту та трастоподібних конструкцій. Ураховуючи величезну кількість трастів, а також різні підходи науковців і практиків до розуміння трасту, нині у світі не існує єдиного, загальновизнаного визначення трасту.

Тому можна виокремити декілька основних підходів до розуміння трасту:

1. Траст - це правовідносини, що виникають між довірителем (первісним власником), довірчим власником та бенефіціаром унаслідок передачі права власності на майно довірчому власнику для досягнення певної мети або для управління цим майном в інтересах вигодонабувачів. Цей підхід є найпоширенішим.

Серед іншого, нова редакція Закону України "Про запобігання та протидію легалізації (відмиванню) доходів, одержаних злочинним шляхом, фрінансуванню тероризму та фрінансуванню розповсюдження зброї масового знищення" від 16.08.2020 р. (далі - Закон про легалізацію доходів) визначає траст саме через категорію "правових відносин".

2. Траст - це зобов'язання, що виникає у довірчого власника/управителя перед бенефіціаром унаслідок передачі майна в управління.

3. Траст - це договір, на підставі якого виникають правовідносини з управління майном. Зазначимо, кла- сичні наукові праці з теорії трастового права одностайно наголошують, що траст не $є$ та не може бути договором і наводять аргументи для цього.

4. Траст - це аналог юридичної особи, створений для досягнення певних цілей (цільовий траст, зокрема і благодійний).

Саме такий підхід покладено в основу Закону України "Про запобігання та протидію легалізації (відмивання) доходів, одержаних злочинним шляхом, фрінансуванню тероризму та фрінансуванню розповсюдження зброї масового знищення", який втратив чинність 28.04.2020 року. У цьому законі траст визначався як юридична особа-нерезидент, яка провадить свою діяльність на основі довірчої власності, де повірений діє за рахунок і в інтересах довірителя, а також зобов'язується за винагороду виконувати певні юридичні дії.

Незважаючи на втрату чинності вказаного вище закону та прийняття нової редакції Закону про легалізацію доходів Податковий кодекс України продовжує практику визнання трастів юридичними особами. Так, у деяких випадках податкові органи можуть кваліфікувати траст як контрольовану іноземну компанію.

На нашу думку, найповнішим $€$ визначення трасту як довірчих правовідносин, що виникають між установником, довірчим власником та бенефіціаром унаслідок передачі установником майна у власність довірчому власнику для управління ним в інтересах наперед визначених осіб (бенефіціарів) та/або для досягнення суспільно-корисної мети на засадах добросовісності, розумності, чесності та розсудливості.

Водночас, поряд із "класичним" англо-американським трастом у різних країнах існує багато різноманітних механізмів управління майном, які узагальнено називають трастоподібні або паратрастові конструкції. Їх можна визначити як інститути права країн, що належать до різних правових систем (континентальної, змішаної, далекосхідної тощо), які ґрунтуються на засадах особливої довіри та разом чи окремо дозволяють досягнути тих же цілей, що і траст у країнах загального права.

Це різноманітні способи (механізми) управління майном, які передбачають передачу майна під контроль (у власність або на іпідставі нших правових титулів) іншій особі з метою ефективного управління.

За своєю правовою природою траст та трастоподібні конструкції можуть відрізнятися, але з їхньою допомогою можуть досягатися аналогічні цілі або можуть виконуватися подібні функції, зокрема:

- ефрективне/професійне управління майном та окремими його видами (наприклад, ЦМК або цінними паперами);

- акумуляція майна для досягнення певних цілей у майбутньому (пенсійні трасти, трасти для оплати освіти);

- збереження майна від самих власників (наприклад, у разі марнотратності, залежності від азартних ігор або поганих звичок);

- управління спадкових майном;

- податкова оптимізація;

- досягнення соціально корисних цілей (благодійні фонди та благодійні трасти).

Основна відмінність між трастом і більшістю трастоподібних конструкцій полягає в тому, що право власності у "класичному" трасті назавжди переходить від первісного власника (довірителя) до довірчого власника (трасті). Саме останній юридично та фактично вважається власником майна у трасті. Тобто у довірчого власника виникають речові права на майно, проте вони обмежені обов'язком діяти у чужому інтересі.

Зазвичай, у трастоподібних конструкціях, що існують у країнах континентальної системи права, власником майна залишається первісний власник, тоді як довірчий 
власник зобов'язаний керувати переданим майном. Відповідно за таких обставин виникають зобов'язальні правовідносини між учасниками (суб'єктами), а речові права на майно залишаються у довірителя.

Нині у світі існує величезна кількість різноманітних видів трастів і трастоподібних конструкцій, які можуть бути класифіковані за різними підставами, зокрема:

I. Залежно від волевиявлення довірителя на прямо виражені трасти (express trusts), передбачувані трасти (implied trusts).

II. Залежно від підстав виникнення, зміни та припинення дії трасту на:

1) ті, що виникають із правомірних дій (договір, документ про створення трасту, рішення уповноваженого органу, заповіт);

2) ті, що виникають із неправомірних дій (конструктивний траст).

III. Залежно від фоорми правочину про створення трасту на:

1) усні - трасти, що виникають на підставі усного розпорядження установника. За загальним правилом відсутня вимога щодо письмової фрорми правочину щодо створення трасту. Він може бути створений шляхом заяви "із вуст в уста" або навіть через поведінку;

2) письмові - трасти, що виникають на підставі належним чином оформленого документа про створення трасту, вираженого у письмовій формі. Нині така форма правочину переважає.

IV. Залежно від можливості внесення змін та відкликання волевиявлення на створення трасту на:

1) відкличні трасти (revocable trusts) - трасти, які можуть бути "відкликані" (припинені) установником у будь-який момент;

2) безвідкличні трасти (irrevocable trusts) - трасти, які можуть бути "відкликані" (припинені) установником лише у випадках, прямо передбачених законом або документом про створення трасту.

V. Залежно від цілі створення трасту на:

1) приватні трасти, тобто створені на користь однієї особи або невеликої групи осіб, наприклад, на користь дітей або батьків установника трасту;

2) публічні трасти - благодійні трасти, створені для певної мети (навчання, охорони здоров'я, екології тощо).

VI. Залежно від того, коли починає діяти траст за життя довірителя чи після його смерті на:

1) прижиттєві (inter vivos trusts) - трасти, які виникають протягом життя установника трасту;

2) спадкові (testamentary trusts) - трасти, які виникають після смерті установника та створюються за заповітом.

VII. Залежно від дій, які має виконувати довірчий власник стосовно переданого майна на:

1) прості трасти (simple trusts) - трасти, "які виникають тоді, коли довірчий власник лише зберігає трастове майно, не виконуючи жодних активних дій. Якщо установник або заповідач передає майно довірчим власникам, щоб вони утримували його у трасті на користь визначеного бенефіціара абсолютно, траст $\epsilon$ простим. Єдиним обов'язком, який має виконувати довірчий власник - передати все або частину майна бенефіціару, якщо документ про створення трасту так наказує. У такому випадку він відомий як "голий" довірчий власник (bare trustee)";

2) спеціальні трасти (special trusts) - трасти, "які виникають, коли довірчий власник призначається, щоб досягати ціль, визначену установником або заповідачем, і таким чином, він зобов'язаний діяти активно при виконанні [умов] трасту. Отже, він відомий як активний довірчий власник". Це більш розповсюджений вид трастів, який передбачає, наприклад, збір платежів, накопичення коштів від управління трастом, інвестиційну дія- льність, вчинення активних дій щодо утримання нерухомого майна тощо.

VIII. Залежно від юрисдикції на:

1) локальні або національні трасти, тобто ті, що виникають, змінюються та припиняються на території однієї країни, де також розміщено майно, передане у траст, а суб'єкти трасту є резидентами тієї ж країни. До таких трастів застосовують право однієї країни;

2) міжнародні або багатоюрисдикційні трасти, тобто ті, які підпадають під юрисдикції кількох країн, а саме: a) учасники трасту є резидентами двох або більше країн; б) майно, передане у траст, перебуває на території країни, відмінної від місця проживання/знаходження учасників трасту, в) юридичні факти, пов'язані з виникненням, зміною або припиненням трасту, мали місце на території іншої країни або г) будь-яка комбінація їхніх вищевикладених випадків. Такі трасти підпадають під дію міжнародного приватного права, тобто до моменту застосування конкретної норми права, має бути визначене належне право, що застосовується до трасту.

VIII. Залежно від того, чи переходить право власності на передане майно від довірителя до довірчого власника, чи ні, можна виокремити власне траст і довірче управління (або його аналог у тій чи іншій країні). На нашу думку, ця підстава для класифрікації $€$ однією 3 найпринциповіших, оскільки фракт переходу права власності від довірителя до трасті, свідчить про виникнення власне "класичного" трасту, тоді як відсутність переходу права власності говорить про виникнення інших правовідносин, як правило, довірчого управління. Це, у свою чергу, тягне за собою визначення специфічних прав та обов'язків усіх учасників довірчих відносин, а також підстав їхнього виникнення, зміни та припинення.

Одним із найскладніших питань у теорії довірчих відносин $є$ питання правової природи прав на майно у різних суб'єктів довірчих правовідносин і поняття й обсяг бенефіціарної власності. Зазначимо, що обсяг повноважень залежить не лише від того, чи це відносини трасту чи інших форм управління майном, але і від конкретної юрисдикції, де виникали відповідні відносини. Такий стан справ пояснюється принципово різними підходами до розуміння титулу власника у країнах загального та континентального права.

Так, у країнах англо-американської системи права існує загальновизнане правило, що у "класичному" трасті право власності назавжди переходить до довірчого власника у момент створення трасту. Із цього моменту первісний власник не лише втрачає свої права на майно, він втрачає можливість здійснювати будь-які дії щодо майна або будь-який вплив на трасті. Юридично та фактично єдиним власником майна визнається довірчий власник, тоді як вигодонабувач має лише бенефіціарний інтерес у трасті, тобто право вимоги до довірчого власника у межах умов документа про створення трасту (наприклад, право вимагати сплати певної частки доходу від управління).

Проте із часом поряд із "класичними" трастами виникло багато конструкцій управління майном, коли юридично право власності на майно переходить, а фактично бенефіціар (може бути або первісним власником, який призначив себе вигодонабувачем, або третьою особою) отримує можливість формально або неформально впливати на процес управління трастом, давати обов'язкові для виконання вказівки довірчому власнику тощо. У такому випадку почали говорити про "номінальні" трасти, тобто трасти, де довірчий власник виконує права власника "номінально". Відповідно у такому випадку передбачається, що вигодонабувач має бенефіціарне право на майно, передане у траст.

Зокрема, у праві України під поняттям бенефіціарної власності йдеться про права фрізичної особи, яка неза- 
лежно від формального володіння має можливість здійснювати вирішальний вплив на управління або господарську діяльність юридичної особи безпосередньо або через інших осіб.

Так, відповідно до п. 30 ч. $1 \mathrm{~cm} .1$ Закону про легалізацію доходів для трастів або для еквівалентних або аналогічних їм осіб кінцевим бенефіціарним власником є: засновник, довірчий власник, захисник (за наявності), вигодоодержувач (вигодонабувач) або група вигодоодержувачів (вигодонабувачів), а також будь-яка інша фрізична особа, яка здійснює вирішальний вплив на діяльність трасту (зокрема через ланцюг контролю/володіння).

Зазначений підхід до розуміння бенефріціарної власності у корені відрізняється від підходів у країнах загального права. Навіть не просто відрізняється, а прямо йому суперечить, що свідчить про те, що на жаль, поняття трасту й інших трастоподібних конструкцій не до кінця зрозуміле навіть для законодавця.

3 іншого боку, треба бути об'єктивним, оскільки схоже розуміння бенефіціарної власності не є новим для контролюючих, зокрема і податкових органів різних країн світу. Він дає можливість уповноваженим органам "пред'являти претензії" справжнім власникам майна, а не особам, які володіють ним лише формально (тобто хоча і є юридичними власниками майна, проте не мають жодного фактичного контролю над майном).

Зазначимо, що в Україні з вищевикладеним тісно пов'язане практичне питання віднесення трастів (або їхніх аналогів, що існують в інших країнах) до контрольованих іноземних компаній (КІК).

Так, Законом України "Про внесення змін до Податкового кодексу України щодо вдосконалення адміністрування податків, усунення технічних та логічних неузгодженостей у податковому законодавстві" від 16.01.2020 року введено нове поняття КІК, під яким розуміється компанія, що зареєстрована за кордоном і перебуває під контролем резидента України. У категорію КІК потрапляють не тільки юридичні особи, а й партнерства, трасти, фонди та благодійні організації. Резидент України, який володіє КІКом, має подати звіти про свої іноземні компанії, якщо:

1) його частка в іноземній компанії становить 50 \% і більше;

2) його частка в іноземній компанії спільно з іншими резидентами України становить не менше $10 \%$ (спільно $50 \%$ і більше);

3) він здійснює фактичний контроль над іноземною компанією.

Якщо перші два пункти не стосуються трастів, оскільки там відсутнє таке поняття як "частка у компанії", то фактор здійснення "фактичного контролю" у трасті $€$ можливим. Крім того, слід розглянути питання щодо юридичного контролю на трастом.

Юридичний контроль над трастом має місце, коли фрізична / юридична особа (як засновник трасту):

1) впливає на прийняття юридично значимих рішень щодо управління трастом, зокрема, визначає юридичну долю майна, погоджує умови щодо істотних умов правочину, дає довірчому власнику вказівки, обов'язкові до виконання;

2) має право вимагати сплати на її користь частки прибутку або доходу (окрім як у межах, чітко визначених умовами трасту);

3) має право прямо або опосередковано розпоряджатися майном, переданим у траст;

4) має право на отримання майна у разі припинення трасту (за винятком випадку, що така особа є бенефріціаром трасту та відповідне право прямо передбачене умовами трасту).
Юридичний контроль над трастом не визнаватиметься у випадках, коли:

1) засновник трасту (довіритель) не має права надавати прямо або опосередковано розпорядження про виплату на його користь прибутку або доходу від управління трастом (за винятком того випадку, коли він $є$ бенефіціаром трасту і така виплата відповідає умовам трасту. I навіть в останньому випадку він має право вимагати здійснення виплати, а не давати обов'язкові вказівки довірчому власнику);

2) засновник не має права розпоряджатися прямо або опосередковано прибутком або доходом, отриманим від управління трастом;

3) засновник не має права на повернення йому майна, що входить до трастової маси (так званого трастового фонду). Іншими словами, траст є безвідкличним;

4) засновник одноособово або спільно з іншими бенефіціарами не мають права припинити дію трасту (крім випадків, прямо передбачених законом або документом про створення трасту);

5) засновник не здійснює фактичний контроль над трастом.

Зокрема, вважається, що фізична/юридична особа здійснює "фактичний контроль" над трастом, коли:

- надає вказівки органам управління КІК (довірчому власнику у трасті), обов'язкові для виконання;

- веде переговори щодо укладення правочинів та погодження істотних умов щодо майна, переданого у траст, які у подальшому лише формально затверджуються або виконуються довірчим власником;

- має довіреність на здійснення суттєвих правочинів від імені КІК, що видана терміном більше, ніж на рік;

- зазначена особа вказана як засновник/бенефріціар/фрактичний вигодонабувач під час відкриття рахунків у банках, де має обслуговуватися траст.

Винятком щодо застосування вказаних вище критеріїв $€$ виконання юристами, адвокатами, бухгалтерами тощо своїх професійних обов'язків під час обслуговування трастів.

Отже, у кожному конкретному випадку, щоб відповісти на питання, чи підпадає траст під визначення КІК, слід враховувати й аналізувати всі обставин справи

3 наведеного можна зробити такий одностайний висновок: поняття трасту загалом і довірчих відносин зокрема вже відоме в Україні. Більше того, не лише відоме, але, як показано вище, воно пройшло певний еволюційний розвиток і становлення.

На відміну від положень законодавства України на початку 90-х років чинне законодавство оперує поняттям трасту, паратрастових конструкцій (їх називають еквівалентами або аналогами трасту), бенефіціарної власності й іншими пов'язаними правовими категоріями. Без сумніву, це позитивне зрушення, але $є$ й інша сторона - якщо проаналізувати положення чинних законодавчих актів, то у більшості випадків поняття трасту певною мірою асоціюється 3 негативом - переховуванням майна, приховуванням інфрормації про кінцевих бенефіціарних власників тощо. Але ж траст - це універсальний інститут, який може використовуватися для досягнення різноманітних легальних цілей (про них ішлося на початку статті). А ось про це законодавство України якраз і мовчить. Винятком можуть бути хіба що положення Цивільного кодексу України про зобов'язальну довірчу власність, договір управління майном і про інститут довірчої власності, що використовується у схемах фрінансування будівництва. Але ж траст та його аналоги можуть використовуватися і у спадковому праві, і в пенсійних правовідносинах, і у благодійності.

Перші кроки для подальшого повноцінного уведення довірчих конструкцій у право України зроблено наприкінці 2020 року, коли побачила світ Концепція рекоди- 
фікації цивільного законодавства, підготовлена групою вчених-цивілістів.

Після тривалих обговорень прийнято компромісне рішення про можливість уведення у право України інституту фрідуціарного фонду як універсального інституту, що поширюється на основні фрідуціарні правові титули довірчу власність та управління чужим майном.

Пропонується, під поняттям фідуціарного фонду розуміти цільове майно, що передається в довірчу власність управителя або в довірче управління. Причому у довірчого власника (управителя) виникають речові права на фідуціарний фонд, тому у розробників Концепції виникла ідея щодо розміщення положень про нього у Книзі 3 у розділі "Інші речові права".

У зв'язку з наведеним виникли питання: 1) наскільки співмірне та як може співвідноситися управління фідуціарним фондом із трастом або іншою трастоподібною конструкцією, що існує у країнах континентального права, наприклад, фрідуцією, що діє у Франції та Молдові, та 2) щодо визнання трасту та трастоподібних конструкцій в Україні.

Паралельно із цим постало питання ратифрікації Україною Гаазької конвениії про право, що застосовується до трастів та їх визнання від 01.07.1985 р. (далі - Конвенція про трасти та/або Конвенція), яка нині $€$ основним міжнародним документом, що регулює трасти та по суті $€$ компромісом між загальною та континентальною системою права в частині регулювання відносин з управління майном.

Відповідно до ст. 2 Конвенції про трасти траст означає правовідносини, створені inter vivos (за життя) або посмертно особою, установником, коли майно було передано під контроль довірчого власника на користь бенеціфріара або для встановленої мети.

Відповідно до Конвенції траст має такі особливості: 1) майно становить відокремлений капітал і не є частиною власності довірчого власника; 2) право на майно трасту належить довірчому власнику чи іншій особі, що виступає від імені довірчого власника; 3) довірчий власник має право й обов'язок, щодо якого він несе відповідальність, управляти, використовувати та розпоряджатися майном відповідно до умов трасту та покладених на нього законом спеціальних обов'язків.

Конвенція про трасти містить колізійні норми, які дають підстави для визнання трастів без обов'язкового введення їх у національне право держави. Цим вдало скористалася Італія, яка, як країна континентальної системи права, не має інституту трасту у власному праві, проте після ратифрікації зазначеної Конвенції має можливість створювати локальні трасти на підставі положень законодавства інших країн, наприклад, Великобританії.

Крім того, Конвенція про трасти створює передумови для визнання трастів як відокремлених цільових фрондів, а також запроваджує уніфіковані правила до визначення права, що підлягає застосуванню до відносин, пов'язаних із передачею майна у траст або управління.

На нашу думку, ця Конвенція не містить жодної норми, яка могла б бути визнана неприйнятною з погляду українського законодавства, проте ії ратифікація дала б Україні змогу активно долучитися до визнання й використання трастів і трастоподібних конструкцій, що існують у різних країнах, без уведення їх у власне національне право.

\section{ВИСНОВкИ}

1. Нерозуміння ідеї трасту призвело до порушення прав громадян, які, постраждали від фінансових афер довірчих товариств, що зіграло не останню роль у формуванні недовірливого або відверто негативного ставлення юристів та звичайних громадян в Україні до трастів та інших довірчих конструкцій упродовж майже двох десятків років.
2. Траст - це довірчі правовідносини, що виникають між установником, довірчим власником і бенефіціаром унаслідок передачі установником майна у власність довірчому власнику для управління ним в інтереcax наперед визначених осіб (бенефіціарів) та/або для досягнення суспільно корисної мети на засадах добросовісності, розумності, чесності та розсудливості.

3. Поняття трасту існує у праві України досить тривалий час, проте у більшості випадків воно певною мірою асоціюється з негативом - переховуванням майна, приховуванням інформації про кінцевих бенефіціарних власників тощо. Крім цього поняття трасту зазнає постійних змін, що свідчить про еволюцію підходів до розуміння цього інституту. Нині траст розуміють як "правовідносини", тоді як попередня редакція закону визначала траст через категорію юридичної особи.

4. Трастоподібні або паратрастові конструкції - це інститути права країн, що належать до різних правових систем (континентальної, змішаної, далекосхідної тощо), які ґрунтуються на засадах особливої довіри та разом чи окремо дозволяють досягнути тих же цілей, що і траст у країнах загального права.

5. У світі існує велика кількість різних видів трастів, які мають свої особливості та які враховують специфіку тієї чи іншої правової системи, де вони функціонують.

6. Підхід до розуміння поняття бенефіціарної власності у трасті відрізняється у країнах загального права та в Україні. В Україні під це визначення підпадає право фізичної особи, яка незалежно від формального володіння має можливість здійснювати вирішальний вплив на управління або господарську діяльність юридичної особи безпосередньо або через інших осіб.

7. Віднесення трасту до КІК залежить від багатьох факторів та має визначатися з урахуванням усіх обставин справи.

8. Нині існує пропозиція введення у право України інституту фрідуціарного фонду, а також ратиффікації Україною Конвенції про трасти.

9. Конвенція про трасти не містить жодної норми, яка могла б бути визнана неприйнятною з погляду українського законодавства, проте ії ратифікація дала б Україні змогу активно долучитися до визнання та використання трастів і трастоподібних конструкцій, що існують у різних країнах, навіть без уведення їх у власне національне право.

\section{Список використаних джерел}

1. Закон України "Про запобігання та протидію легалізації (відмиванню) доходів, одержаних злочинним шляхом, фінансуванню тероризму та фінансуванню розповсюдження зброї масового знищення" від 06.12.2019 № 361. URL: https://zakon.rada.gov.ua/laws/show/361-20\#Text;

2. Закон України "Про запобігання та протидію легалізації (відмивання) доходів, одержаних злочинним шляхом, фінансуванню тероризму та фінансування розповсюдження зброї масового знищення" від 14.10.2014 р. № 1702. URL: https://zakon.rada.gov.ua/laws/show/1702-18\#Text;

3. Закон України "Про внесення змін до Податкового кодексу України щодо вдосконалення адміністрування податків, усунення технічних та логічних неузгодженостей у податковому законодавстві" від 16.01.2020 року № 466. URL: https://zakon.rada.gov.ua/laws/show/466-20\#Text;

4. Концепція оновлення Цивільного кодексу України. Київ: Видавничий дім "АртЕк", 2020. 128 с

5. Гаазька конвенція про право, що застосовується до трастів та їх визнання від 01.07.1985 p. URL: https://www.hcch.net/en/instruments/ conventions/full-text/?cid=59.

\section{References}

1. Zakon Ukrayiny. (2019) Pro zapobihannya ta protydiyu lehalizatsiyi (vidmyvannyu) dokhodiv, oderzhanykh zlochynnym shlyakhom finansuvannyu teroryzmu ta finansuvannyu rozpovsyudzhennya zbroyi masovoho znyshchennya. [On Prevention and Counteraction to Legalization (Laundering) of Proceeds from Crime, Financing of Terrorism and Financing of Proliferation of Weapons of Mass Destruction, Law of Ukraine] № 361. URL: https://zakon.rada.gov.ua/laws/show/361-20\#Text (in Ukrainian);

2. Zakon Ukrayiny. (2014) Pro zapobihannya ta protydiyu lehalizatsiyi (vidmyvannyu) dokhodiv, oderzhanykh zlochynnym shlyakhom, finansuvannyu teroryzmu ta finansuvannyu rozpovsyudzhennya zbroyi masovoho znyshchennya. [On Prevention and Counteraction to Legalization (Laundering) of Proceeds from Crime, Financing of Terrorism and Financing 
of Proliferation of Weapons of Mass Destruction, Law of Ukraine] № 1702. URL: https://zakon.rada.gov.ua/laws/show/1702-18\#Text (in Ukrainian);

3. Zakon Ukrayiny. (2020) Pro vnesennya zmin do Podatkovoho kodeksu Ukrayiny shchodo vdoskonalennya administruvannya podatkiv, usunennya tekhnichnykh ta lohichnykh neuz'hodzhenostey u podatkovomu zakonodavstvi [On Amendments to the Tax Code of Ukraine to Improve Tax Administration, Eliminate Technical and Logical Inconsistencies in Tax Legislation] № 466. URL: https://zakon rada gov ua/laws/show/466-20\#Text (in Ukrainian);

G. Buyadzhy, Dr. Sc. (Law), Associate Prof.

Taras Shevchenko National University of Kyiv, Kyiv, Ukraine

\section{EVOLUTION OF THE FIDUCIARY RELATIONSHIP DOCTRINE IN INDEPENDENT UKRAINE: FROM COMPLETE OBJECTION TO IMPLEMENTATION INTO CURRENT LEGISLATION}

The article addresses the development of the fiduciary relationship doctrine in Ukraine. Primarily, the paper covers the alteration in understanding the idea of trust and other trust-like constructions by Ukrainian society from the 90 s of the XX century to present time.

The purpose of the article is to highlight the main stages of and approaches to understanding of fiduciary relationship in general and trust and other trust-like constructions in particular, as well as to analyse their common and distinctive features in comparison to related legal institutions and to determine the prospects for their further implementation in Ukrainian law.

Methodology. To shed the light on different approaches to understanding trusts and paratrust constructions, a comparative-historical method was used in the article; also the methods of analysis, ascent from abstract to concrete and system-structural methods of scientific cognition were applied.

Results and conclusions. Misunderstanding of the idea of a trust has led to violation of the rights of citizens affected by financial fraud of trust companies, which has played a significant role in shaping the distrustful or negative attitude of lawyers and ordinary citizens of Ukraine to trusts and other trust-like constructions for almost two decades.

The concept of trust has existed in the law of Ukraine for a long time, but mostly it is associated with the negative issues like hiding property, hiding information about the ultimate beneficial owners etc. In addition, the concept of trust is changing constantly; this indicates the evolution of approaches to understanding the institution. At present, a trust is understood as "legal relationship," while the previous version of law defines a trust through the category of a legal entity.

The approach to understanding the concept of beneficial ownership in a trust differs in common law countries and Ukraine. In Ukraine, this definition covers the right of a natural person who, regardless of formal ownership, has the opportunity to exercise decisive influence over the management or economic activity of a legal entity directly or through other persons.

Keywords: fiduciary relationship, trust, trust-like (paratrust) constructions, property management, Trust Convention, beneficial ownership, trustee, ultimate beneficial owner, beneficiary, controlled foreign company (CIC), revocable trusts, irrevocable trusts.

Bulletin of Taras Shevchenko National University of Kyiv.

Legal Studies, 2021; 3 (118): 14-21

УДК $342.95 ; 34: 61 ; 342.951: 615$

DOI: https:doi.org/10.17721/1728-2195/2021/3.118-3
ISSN 1728-2195

(C) Taras Shevchenko National University of Kyiv Publishing center "Kyiv University", 2021

Р. Ю. Гревцова, канд. юрид. наук, доц.

\section{РОЗВИТОК НАУКОВО-ВИКЛАДАЦЬКОЇ ДІЯЛЬНОСТІ У СФЕРІ ПРАВА ОХОРОНИ ЗДОРОВ'Я ЯК ЗАПОРУКА ФОРМУВАННЯ СУЧАСНОГО УКРАЇНСЬКОГО ЮРИСТА (ДОСВІД КИЇВСЬКОГО НАЦІОНАЛЬНОГО УНІВЕРСИТЕТУ ІМЕНІ ТАРАСА ШЕВЧЕНКА)}

Охорона здоров'я є однією з найважливіших сфер життєдіяльності держави і суспільства. Функціонування і розвиток охорони здоров'я вимагають належного правового забезпечення, яке можливе лише за наявності кваліфікованих юридичних кадрів, що мають ґрунтовні знання та навички в царині права охорони здоров'я. У статті розглянуто концепт права охорони здоров'я, який є новим для української правничої науки, та його складові - медичне право, право охорони громадського здоров'я та фармацевтичне право. Досліджується досвід викладання дисциплін, що належать до царини права охорони здоров'я, у Київському національному університеті імені Тараса Шевченка, який є флагманом вітчизняної вищої освіти, зокрема і юридичної. Саме на юридичному факультеті (нині - Інститут права) Київського національного університету імені Тараса Шевченка студентам магістратури вперше в Україні почали викладати інноваційну дисципліну "Правове регулювання охорони громадського здоров'я" ("Право охорони громадського здоров'я"), а 2019 року запроваджено унікальну магістерську спеціалізацію (вибірковий блок навчальних дисциплін) - "Право охорони здоров'я".

Розглянуто ключові завдання, на виконання яких спрямовані дисципліни, що викладаються в межах магістерської спеціалізації "Право охорони здоров'я" (усього 12 дисциплін). Проаналізовано перелік і зміст дисциплін спеціалізації, серед яких можна умовно виокремити три блоки: ключові дисципліни, що розкривають "складові" права охорони здоров'я; дисципліни, що забезпечують розуміння студентами специфіки діяльності у сфері охорони здоров'я та юридичних інструментів, які використовують для управління галуззю та менеджменту закладів охорони здоров'я; а також дисципліни, спрямовані на висвітлення актуальних тем і проблем права й етики в охороні здоров'я та набуття студентами практичних навичок захисту прав суб'єктів правовідносин у галузі охорони здоров'я. У статті зазначено, що під час викладання дисциплін спеціалізації "Право охорони здоров'я" основний акцент робиться на ознайомленні студентів із реаліями практики, звертається увага на використання сучасних методів і підходів до викладання та навчальних технологій, які дозволили забезпечити високу ефективність навчання, зокрема в умовах карантину, викликаного поширенням коронавірусної хвороби COVID-19. Також окреслено основні складові навчально-наукової діяльності у сфері права охорони здоров'я, зокрема діяльності, що здійснюється Навчально-науковим центром медичного права Інституту права університету. Зроблено висновок про те, що в Київському національному університеті імені Тараса Шевченка створено власну наукову школу права охорони здоров'я.

Ключові слова: право охорони здоров'я, медичне право, фармацевтичне право, охорона здоров'я, громадське здоров'я, право охорони громадського здоров'я, магістерська спеціалізація, науково-викладацька діяльність.

\section{ВСТУП}

У рік 30-річчя незалежності України ми підводимо підсумки та формуємо бачення подальшого розвитку українського суспільства і держави. Запорукою їхнього успішного розвитку $€$ сучасна, якісна освіта, а також охорона здоров'я, яка відповідатиме потребам людини. Тож підготовка фахівців для сфери охорони здоров'я залишається вкрай актуальною. Вона має охоплювати не лише підготовку медичних і фармацевтичних працівників та управлінців у сорері охорони здоров'я, а й правників, зда-

(๖ Гревцова Р. Ю., 2021 